\title{
DEVELOPMENT COOPERATION AND PARTNERSHIP IN THE MIRROR OF SOCIAL VALUES
}

\author{
ÁKOS BODOR \\ Junior research fellow \\ Hungarian Academy of Sciences Centre for Regional Studies Transdabubian Research Institute \\ 7601 Pécs, P. O. Box 199. \\ bodor@rkk.hu
}

\begin{abstract}
The current theories of governance and economic development require the possession of certain social values. The spreading of these values is poor in the Hungarian society. Accordingly, real development cooperation activities and real bottom-up organised partnership networks in Hungary are not frequent phenomena. It seems that the early results of a research project in the agglomeration of Pécs verify this hypothesis.

Keywords: cooperation, social values, governance, agglomeration
\end{abstract}

\section{INTRODUCTION}

This paper was made apropos of a research project started in 20101. The research investigates the particular questions of the institutionalization of urban areas (agglomerations) in Hungary. The main goal is to provide possible institutional models for the wider development of these areas. The project has an interdisciplinary approach in which an important element is to detect existing cooperation forms, interorganizational relations and networks.

Cooperation between the city and its neighbourhood is motivated by common goals which rely on common interests of the given community. These joint activities are embodied very often in different development activities, in strong partnerships or turn to an enduring network which form establishes a development coalition with the active participation of local/territorial actors. Since the operation of these types of activities is embedded in the broader society their characteristics cannot be independent from it.

\section{GOVERNANCE AS THE IDEA OF COOPERATION}

The shift from government to governance in Western societies was one of the most significant political trend in the last decades. Whereas government is connected with top-down approaches

1 "Particular questions of institutionalization of agglomerations" (OTKA 81789). Supported by Hungarian Scientific Research Fund. 
of command and control systems, governance builds on self-adjusting group of different types of actors. These groups of actors cooperate tightly together in interactive networks. The substances of governance are the various ways of operating which do not rely on the power of the state (Stoker, 1997). The definitions of governance are very diverse and inconsistent (Pálné, 2008, Petrers, Pierre, 2006, Rhodes, 1997, Stoker, 1997, Osborne, 2010). Despite the definitional uncertainty it can be stated that governance literature deals with relationships of various organizations, mainly the exchange between the state and society. Theories highlight the importance of diversity in cooperation so from this point of view governance is in fact outlined in the pattern of interactions. This pattern reveals the process and influential rules which are determining in the achievement of goals and shows blurred boundaries between public- and private spheres (Peters, Pierre, 1998).

In Rhodes' conception (Rhodes, 1997) self-organizing and inter-organizational networks can be an alternative to market and hierarchy. These networks consist of actors of the public- and semipublic spheres which are characterized by source-dependency and source-exchange. They develop a common policy along the continuous negotiations. This process results in a significant autonomy against the state. Sjöblom and Godenhjelm (2009) define the most typical governance tools; which are - among others - soft law, networking and partnership. Furthermore projects are very important tools as well with the various temporary organizations established in connection with the implementation of projects. According to the authors these tools represent a transition from the systems based on command to the systems based on cooperation. These informal governance tools cannot operate in the framework of a traditional top-down approach. So they require dense textured interactions between local governments and civil society which materialize in horizontal and vertical linkages.

\section{BOTTOM UP ECONOMIC DEVELOPMENT AS THE IDEA OF COOPERATION}

In parallel with the change in political leadership serious modifications in economic development theories have also emerged. The interventions led by governments are often discredited, instead the literature currently promotes bottom-up local economic initiatives which rely on endogenous characteristics of the respective areas/regions (Lengyel, 2010). According to this new paradigm, local economic development processes should involve local municipalities, local entrepreneurs, NGOs etc. (Horváth, 1998, Rechnitzer, 1998). The framework of their cooperation is the regional network, which can be described as "a process in which several participants or groups of participants are involved who work towards a common goal on the basis of a common conviction or vision. This process is not, as a rule, based on formal contracts, but is founded on trust, partnership and the conviction that all those concerned profit from it." (Sprenger, 2001, 6).

Urban regime analysis has been one of the most significant urban public policy theories in the last twenty years. It is not considered expressly as an economic development theory even though it has a number of linkages to local economic development. The first urban regime case studies attempted to describe relations between public and private actors in U.S. cities. Shortly they started to extend their application to the analysis of broader areas i.e. from regional level to urban neighbourhood (Mossberger, Stoker, 2001).

According to urban regime theory power is fragmented and local public and private actors can "join their force" through different cooperation forms. The actors cooperate in order to achieve the most effective local governing. Urban regime is a "living organism", "a mediator" or "a bridge" between the private and the public sphere (Stone, 1993). 
Four elements are key to elaborating such governing coalitions (Stone, 2005):

- an agenda to address a distinct set of problems;

- a governing coalition formed around the agenda, including typically both governmental and nongovernmental members;

- resources for the pursuit of the agenda, brought to bear by members of the governing coalition; and

- given the absence of a system of command, a scheme of cooperation through which the members of the governing coalition align their contribution to the task of governing.

According to Iwona Sagan (2009) urban regime is a proper framework for understanding the process of new regionalism in Central-East Europe. The author emphasizes that governing coalitions are strongly context-dependent so it is not possible to separate their analysis from cultural and historical specialities.

\section{PATTERNS OF URBAN NEIGHBOURHOOD COOPERATION IN THE PÉCS AGGLOMERATION}

After a sketchy demonstration of the role of cooperation in theoretical paradigms, the next section attempts to describe several characteristics of the Hungarian urban neighbourhood relations. Empirical findings are taken from the research project "Particular questions of the institutionalization of agglomerations" conducted by the Transdabubian Research Institute of the Centre for Regional Studies of the Hungarian Academy of Sciences. The fieldwork focuses on urban areas of three Hungarian cities (Miskolc, Győr, Pécs). Since the fieldwork is underway (in November 2011) the results are limited and confined to the Pécs agglomeration. Despite this fact there are certain trends which are already visible in the early phase. This paper investigates only the different types of cooperations, it does not aim to explain the general mission of the whole research project.

The first item of fieldwork covered 30 settlements around the city of Pécs. This research area overlaps only partly the current public administration units; namely these settlements belong to three different microregions (NUTS 4): Pécs Microregion, Komló Microregion and Mohács Microregion. Furthermore, the selected settlements coincide only partially with the official classification of the Pécs agglomeration by the Hungarian Central Statistical Office (KSH 2003). The research uses an extended sample of settlements compared to the official classification. This enlargement was justified by several indicators and statistical data. On the basis of these indicators we could presume that proximity of the City had a significant effect on the selected settlements.

As a consequence of the nature of the Hungarian settlement structure the analyzed area is not comparable with metropolitan areas. Nevertheless it can be interpreted as a functional area or as an urban region where agglomeration and suburbanization processes are observable (Somlyódyné, 2011). Furthermore "the administrative borders of local and territorial governments differ from the functional borders and from the natural flow of population and economy so conflicts and competitive situations occur. The most capable resolution of these problems is cooperation. Cooperation will establish unity of urban region." (Somlyódyné, 2011, 30).

In the course of fieldwork in the Pécs agglomeration 70 interviews were completed (with complex, half-structured questionnaires) with the key actors of the analysed area. In one part, questions were asked about the patterns of cooperation and organizational relationships, the other part consisted of questions on facts and opinions about the functioning of the local economy, society and public administration. 
The main groups of interviewees according to organizational types are the following:

a) Local municipalities (mayor)

b) Enterprises (most significant enterprises of the given settlement)

c) Civil organizations (most significant civil organizations of the given settlement)

d) "Other" types of organizations (e.g. development agencies, chambers, clusters)

The next paragraphs explain the acquired empirical experiences based on the first three groups. Analyses attempt to reveal respondents' ego-network by means of predefined categories. These categories contain all of the potential and relevant actors of local development networks based on the literature. The possible geographical levels of cooperation were classified by the following categories: local, neighbouring settlements, microregional, county, regional, national, abroad. Other types of questions (mostly open questions) aim to grasp the quality of these relations.

\section{RELATIONSHIPS AMONG THE KEY ACTORS WITHIN SETTLEMENTS}

The first results of the research show that strong and enduring relations can be found among the key actors mostly on local level. On this level there are a great deal of linkages among local municipalities, local enterprises and local civil organizations. It means that those enterprises and civil organizations which were visible for the research (namely the more significant ones) and the local municipality are usually in connection with each other.

In case of local municipalities the total amount of their business linkages are established dominantly in their cooperation with local enterprises. Of course this statement can be interpreted inversely as well, namely the total amount of public linkages of business actors corresponds dominantly to the local municipality of their seat. It is a frequent set of local arrangements in analysed settlements that the mayor holds the position not as a full-time job but he/she manages his/her own private company in parallel. Many times these enterprises are the biggest employers of the settlement. In these cases the public-private cooperation is embodied in the person of mayor.

About the relationship of local municipalities and civil organizations it can be stated in general that cooperation operates mostly on local level. However these relationships show usually serious inequalities because relatively small number of local civil actors have their income predominantly from the local municipality. This phenomenon is a typical manifestation of the weak and underdeveloped Hungarian civil society.

Interactions between civil organizations and enterprises on local level are relatively dense as well. The content of these relations are fundamentally sponsoring of civil organizations by companies.

To summarize local level relationships of key actors it can be stated that in almost all settlements some kind of configuration of cooperation can be detected among the three key sectors with the local municipality in central position. The content of the cooperation covers local issues.

\section{RELATIONSHIPS OF KEY ACTORS OUTSIDE THE SETTLEMENT}

As we leave the world of local activities behind, the structure of cooperation is significantly changing. The boundaries between sectors become more rigid and the level of interaction is low compared with the number of possible variations.

In case of enterprises there are active relationships in all geographical categories with other enterprises in connection with their business activities. On the other hand, a crucial part of the poor linkages of civil actors is directed toward other similar types of civil actors located in neighbouring settlements. 
The relations between municipalities are notable especially between neighbouring settlements and between settlements belonging to the same microregion. In the background of these active cooperation activities are service provision as an obligation of local municipalities which materialize on the level of the microregion through a municipal association. It was a long process until the current arrangement evolution (Kovács, Lados, Somlyódyné, 2008; Kovács, 2008). In this process central government motivated local governments through financial norms and incentives for cooperation. Accordingly it is important to see that these partnerships in many cases came into existence in a constrained form: "Membership in Multipurpose Microregional Associations is theoretically voluntary but in reality is organized by necessity. The financial status of local municipalities does not allow them to keep away from the mainstream" (Kovács, 2008, 215).

The Municipality of the city of Pécs including the enterprises and civil actors from the core settlement of the agglomeration, but do not appear as particularly important partners.

\section{EXTERNAL RELATIONS OF KEY ACTORS}

Beside the representatives of key actors there are further actors which have a very important role in the development of an area (Horváth, 1998, Rechnitzer, 1998, Lengyel, 2010). The following types of actors were identified in the questionnaire in order to investigate key actors' relationships to them:

a) territorial development organizations, rural development organizations

b) economic development organizations

c) professional associations

d) universities

e) research institutes

Relations with territorial development organizations and with rural development organizations show no variety: the only type of actor mentioned is the LEADER organization. LEADER non-profit organizations were established and covered the whole country in order to implement the New Hungarian Rural Development Programme. LEADER was originally an experimental rural development program in the old member states of the EU whereas in Hungary LEADER functions rather as a distribution platform of financial assistance. The essence of the LEADER approach can be summarized in seven key features (Fact Sheet 2006):

- Area-based local development strategies;

- Bottom-up elaboration and implementation of strategies;

- Local public-private partnerships: local action groups;

- Integrated and multisectoral actions;

- Innovation;

- Cooperation;

- Networking.

The Program implementation in Hungary excludes settlements over 10000 inhabitants so considering our research area the importance of LEADER would be moderate for us. Nevertheless, the Program should have an effect on the patterns of cooperation in the analysed area according to its philosophy and principles. In reality linkages to LEADER are double faced: all the three types of key actor representatives mentioned their connection to the LEADER Program but beyond this fact no cooperation is evoked.

As regards the linkages to economic development organizations and to professional associations it can be stated that enterprises have relations with both types of organizations on the different 
geographical levels as well. However these relations seem rather formalized and less lively. There is a similar situation between municipalities and their professional associations. The cooperation between municipalities and economic development organizations is not at all a typical form in the analysed area.

Cooperation with universities and research institutes is very rare in all the tree types of key actors.

\section{PATTERNS OF COOPERATION IN THE PÉCS AGGLOMERATION}

According to the available results of the research it would seem that there is no urban regime, development coalition or regional network which could fit into the theoretical criteria demonstrated in the first part of this paper. The revealed cooperation patterns among the studied actors do not indicate a pursuit for common goals or vision in order to achieve the joint development of the Pécs Urban Region.

This result is not surprising in light of the social value system of the Hungarian society. The next section will present a couple of cultural barriers in the current Hungarian society which can hinder the cooperation of actors.

\section{VALUES IN THE HUNGARIAN SOCIETY IN LIGHT OF COOPERATION}

It is not questionable in the course of studying literature cited in this paper that certain cultural elements are crucial in the implementation of current development activities. Sociology uses the term culture in a broad meaning accordingly the key elements of the culture are behaviour patterns, norms, values, beliefs and scientific knowledge in a society (Andorka, 2006). Considering cooperation as a fundamental driving force of economic competitiveness it is a vital question whether a society (nation or region) is able to adapt the cultural preconditions of cooperation or not. Those societies in which the culture of cooperation is not so prevailing face a big challenge. This challenge requires a huge work hence changing the culture is necessarily a slow process. Culture can reproduce itself through the channels of socialization. In addition, the values which constitute the core of culture (Hofstede, 2001) are acquired already in early childhood so their operation in people's activities is very often unconscious. The German sociologist Ralf Dahrendorf said about the perspective of Central-East European post-socialist countries that it took six months to replace a political system, six years to transform an economic system, and 60 years to change a society (Dahrendorf, 1990).

The Hungarian value sociology had a significant contribution in the last decades to understanding the value system of Hungarian society (eg. Hankiss, 1989, Füstös, Szakolczay, 1999, Varga, 2003). A detailed presentation of their results would exceed the framework of this paper. Summing up the main findings it can be stated that since decades Hungarian society is characterized by - among others - distrustfulness, low level of cooperative forms, high level of uncertainty avoidance and high level of paternalistic attitudes. Hungarian sociologist 30 years ago Elemér Hankiss wrote the following statement about cooperation which is still valid in our days: "The value structure of the Hungarian society is fragmented, full of contradictions and it has rather community-destroyer than community-builder function. To say the least: it does not promote development of communities" (Hankiss, 1983, 236).

The International Social Justice Project (ISJP) was a comparative international research investigating the new economic and social structure in Central-East European transition countries with a special focus on differences from West-European features (Csepeli et al., 2004). During the exami- 
nation of the social judgment of personal success and enrichment they found an interesting paradox in the judgment of relational capital. Ideally relations come into existence through mobilizing internal resources and in this way they are a crucial condition of success. However "good relation" has another possible meaning namely when somebody achieves his/her goals in an unmerited way and dishonestly. This can lead to corruption, personal interlocking, clientelism and paternalism on macro-level. In the ISJP research relations were used in the latter meaning because in Central-East European countries they found a negative correlation between internal resources and relations. In other words according to their results relational capital as an attribute of success correlates negatively with individual skills and efforts while positively with external fortunate starting circumstances. Regarding the phenomenon of enrichment the importance of the role of relations correlates most closely with dishonesty, unequal opportunities and with unequal external economic factors while it correlates negatively with hard work and talent.

The World Values Surveys (WVS) research project has collected data from 1981 regularly in the form of representative national surveys about values, attitudes, motivations and their change in different societies (Inglehart, 1997, Inglehart, Baker, 2000, Inglehart, Welzel, 2005, 2009). The WVS in collaboration with EVS (European Values Study) carried out surveys in 97 societies containing almost 90 per cent of the world's population. The research uses a standardized questionnaire that measures changing values concerning religion, gender roles, work motivations, democracy, good governance, social capital, political participation, tolerance of other groups, environmental protection and subjective wellbeing. The most relevant statements of the fifth wave of WVS about the Hungarian value structure are the following (Keller, 2010, Tóth, 2009, Rádai, Tóth, 2010):

- Level of trust in institutions, politicians, business organizations, government, the media, trade unions and public authorities is extremely low compared with other countries.

- Participation in civil society is extremely low as well.

- Hungarians socialize with neighbours least in Europe.

- Two-thirds of Hungarians think that they are honest but their compatriots are not.

- Four-fifth of Hungarians think that no one can become rich in Hungary with honest work; and those who wish to succeed need to break certain rules.

- Hungarians are less critical of tax fraud and unlawful access to state aid than people in Poland or the Czech Republic and relatively tolerant towards petty offences: getting a free ride on public transport is a forgivable sin.

- Hungarians have the strongest belief that economic actors can prosper only at the expense of each other. In other words, business is a zero-sum game.

- Attitudes of uncertainty avoidance are very widespread. Hungarians think that the state is bound to guard its citizens from a wide range of threats but, in terms of the individual's readiness to assume risks, they are behind the average in the European Union

\section{CONCLUSION}

The current theories of governance and economic development inevitably reflect the social values of the society in which they were born. Accordingly, essential dispositions of the traditional western democracies are the basis for them. Of course, it does not mean that in these theories different features of societies would not be take into account. After all, it would be necessary - in case of new democracies - to give a more significant role in development policies to the shaping of these societal 
factors. The doubtful materialization of principles of development policies in certain new member states causes primarily social barriers not only financial, coordination or administrative problems.

\section{REFERENCES}

Andorka R., 2006, Bevezetés a szociológiába, Budapest, Osiris.

Bache I., Flinders M., 2005, Multi-level Governance, Oxford, Oxford University Press.

Csepeli G., Örkény A., Székelyi M., Barna I., 2004, Bizalom és gyanakvás. Szociálpszichológiai akadályok a piacgazdasághoz vezetö úton Kelet-Európában, Szociológiai Szemle, 1: 3-35.

Dahrendorf R., 1990, Reflections on the Revolution in Europe, London, Chatto and Windus.

Fact Sheet. The Leader approach, 2006, Office for Official Publications of the European Communities, Luxembourg.

Finta I., 2009, A Leader Program végrehajtásának aktuális kérdései Magyarországon, Vidék Hangja Magazin, www. mnvh.hu.

Füstös L., Szakolczai Á., 1999, Kontinuitás és diszkontinuitás az értékpreferenciákban (1977-1998), Szociológiai Szemle, 9: 54-73.

Hankiss E., 1983, Társadalmi csapdák. Diagnózisok, Budapest, Magvető Kiadó.

Hankiss E., 1989, Kelet-európai alternatívák, Budapest, Közgazdasági és Jogi Könyvkiadó.

Hofstede G., 2001, Cultures Consequences, London, Sage Publications.

Horváth G., 1998, Európai regionális politika, Budapest-Pécs, Dialóg Campus.

Inglehart R., 1997, Modernization and Postmodernization. Cultural, Economic, and Political Change in 43 Societies. Princeton, Princeton University Press.

Inglehart R., Baker W.E., 2000, Modernization, cultural change and the persistence of cultural values, American Sociological Review, 65: 19-51.

Inglehart R., Welzel C., 2005, Modernization, Cultural Change and Democracy, New York, Cambridge University Press.

Inglehart R., Welzel C., 2009, How Development Leads to Democracy: What We Know about Modernization, Foreign Affairs, 2: 33-48.

Keller T., 2010, Hungary on the world values map, Review of Sociology, 1: 27-51.

Kovács K., 2008, Kényszer szülte és önkéntes együtt müködések a kistelepülési önkormányzatok körében, in Somlyódyné Pfeil, E., Kovács, K. (eds.): Függőben. Közszolgáltatás szervezés a kistelepülések világában, Budapest, KSZK ROP Programigazgatóság, 211-234.

Kovács K., Lados M., Somlyódyné Pfeil E., 2008, Közszolgáltatás-szervezési kihivások kistelepülési környezetben. in Somlyódyné Pfeil, E., Kovács, K. (eds.): Függőben. Közszolgáltatás szervezés a kistelepülések világában, Budapest, KSZK ROP Programigazgatóság, 9-45.

Központi Statisztikai Hivatal Baranya Megyei Igazgatósága, 2003, Pécsi agglomeráció. Pécs, KSH Baranya Megyei Igazgatósága.

Lengyel I., 2010, Regionális gazdaságfejlesztés. Versenyképesség, klaszterek és alulról szervezödö stratégiák, Budapest, Akadémiai Kiadó.

Mossberger K., Stoker G., 2001, The evolution of urban regime theory, Urban Affairs Review, 6: 810-835.

Osborne S.P., 2010, Introduction. The (New) Public Governance: a suitable case for treatment? in Osborne S.P. (ed.) The New Public Goverance? Emerging perspectives on the theory and practice of public governance, New York-London, Routledge, 1-16.

Pálné Kovács I., 2008, Helyi kormányzás Magyarországon. Pécs-Budapest,Dialóg Campus. 
Peters B.G., Pierre J., 1998, Governance without government? Rethinking public administration, Journal of Public Administration Research and Theory, 2: 223-243.

Peters B.G., Pierre J., 2006, Introduction, in Peters B.G., Pierre J. (eds.) Handbook of Public Policy, London, Sage, 1-11.

Rádai E., Tóth I.G., 2010, Closer to the East or the West? Eurozine. The Hungarian Quarterly, 51: 70-77.

Rechnitzer J., 1998, Területi stratégiák, Budapest - Pécs, Dialóg Campus.

Rhodes R.A.W., 1997, Understanding Governance, Policy Networks, Governance, Reflexivity and Accountability, Philadelphia, Open University Press.

Sagan I., 2009, Regions, New Regionalism and Regime Theory: Deciphering Post-Socialist Institutional Change, in: Scott, J. (ed.) De-coding New Regionalism. Farnham, Ashgate, 93-113.

Sjöblom S., Godenhjelm S., 2009, Project proliferation and governance: implication for environmental management, Journal of Environmental Policy \& Planning, 11: 169-185.

Somlyódyné Pfeil E., 2011, Az agglomerációk jelentőségének változása az államszervezés és a városi kormányzás szempontjából, Tér és Társadalom, 3: 27-59.

Sprenger R.U., 2001, Iner-firm Networks and Regional Networks, Bonn, ADAPT.

Stoker G., 1997, Governance as theory: Five prepositions, International Social Science Journal, 50: $17-28$.

Stone C.N., 1993, Urban regimes and the capacity to govern: a political economy approach, Journal of Urban Affairs. 15: 1-28.

Stone C.N., 2005, Looking back to look forward. Reflections on Urban Regime Analysis, Urban Affairs Review, 40: 309 -341.

Tóth I., 2009, Bizalomhiány, normazavarok, igazságtalanságérzet és paternalizmus a magyar társadalom értékszerkezetében, Budapest, TÁRKI.

Varga K., 2003, Értékek fénykörében, Budapest, Akadémiai Kiadó. 
EUROPA XXI, 4-Powiązania handlowe Polski z Europą. Z debaty o przyszłym kształcie zjednoczonej Europy

EUROPA XXI, 5-Przestrzeń ekologiczna Polski. Dekolektywizacja rolnictwa i sytuacja zdrowotna w Europie Środkowej, Wschodniej i Południowo-Wschodniej

2001

EUROPA XXI, 6-Integracja europejska-dylematy spójności i konwergencji regionalnej

2002

EUROPA XXI, 7-Slovakia and Poland. Urban, social and demographic questions. Relation between neighbours

2003

EUROPA XXI, 8-European space in the face of enlargement. The West to East European Trajectory Project

EUROPA XXI, 9-Polska i Europa. Kształtowanie przestrzeni wolności

EUROPA XXI, 10 - Society and environment. Towns and settlement in Europe

2004

EUROPA XXI, 11-Przestrzeń Europy. Przestrzeń Unii Europejskiej

2005

EUROPA XXI, 12-Central and Eastern Europe: changing spatial patterns of human activity EUROPA XXI, 13-New spatial relations in new Europe

\section{6}

EUROPA XXI, 14 - Core and peripheral regions in Central and Eastern Europe

EUROPA XXI, 15--Regional periphery in Central and Eastern Europe

\section{7}

EUROPA XXI, 16-Regional development in Central Europe - cohesion or competitiveness

\section{8}

EUROPA XXI, 17-New functions of rural and industrial space in Central and Eastern Europe

EUROPA XXI, 18-Territorial dilemmas of socio-economic development in Europe

\section{9}

EUROPA XXI, 19—European urban system: metropolization and networking

\section{0}

EUROPA XXI, 20-European Union external and internal borders interactions and networks EUROPA XXI, 21-Environmental and infrastructural networks 
Free copy

$$
\begin{gathered}
\text { PL - ISSN 1429-7132 } \\
\text { STANISŁAW LESZCZYCKI }
\end{gathered}
$$

INSTITUTE OF GEOGRAPHY AND SPATIAL ORGANIZATION, PAS 